\title{
International tourism, vulnerability, and disaster capitalism
}

\author{
S. C. Stonich \\ Department of Anthropology, Environmental Studies Program, \\ University of California, Santa Barbara, California, USA
}

\begin{abstract}
Recently, Naomi Klein critiqued "the rise of disaster capitalism," an emerging orientation in international development institutions to exploit natural and human disasters in order to expedite the expansion of neoliberal capitalism. Klein identifies the promotion of high-end tourism as a principal means of advancing disaster capitalism. Based on ethnographic and survey research conducted in Honduras between 1980 and 2004, this paper uses the example of Hurricane Mitch in 1998 to assess the relevance of "disaster capitalism" to describe disaster assistance in the aftermath of this "natural" disaster. It focuses on the promotion of international tourism as a major economic development strategy during recovery and reconstruction. It examines the actions of, and the linkages among, the Honduran state $(\mathrm{GOH})$, international donors, the private sector, and civil society organizations during this period. Hurricane Mitch in Honduras is an appropriate case to consider because it has been identified as the point at which disaster capitalism hit its stride; it has been 7 years since Mitch and several assessments of recovery and reconstruction efforts have been completed; and thus, lessons learned (and not learned) from the experiences of Hurricane Mitch can be applied to other cases. The paper concludes that although international tourism has been a major development strategy in Honduras before and since Hurricane Mitch, "disaster capitalism" only partially captures the myriad processes and phenomenon involved. While international tourism has grown significantly in Honduras in recent years, the potential of international tourism to affect broad social and ecological transformations, reduce vulnerability, and enhance resilience, has not been realized.
\end{abstract}

Keywords: disasters, tourism, Hurricane Mitch, disaster assistance, disaster capitalism, vulnerability, resilience, Honduras. 


\section{Introduction}

International tourism exceeded expectations, growing by $5.5 \%$ to 808 million arrivals in 2005, despite devastating natural disasters, including an extraordinarily long hurricane season in the Caribbean and the aftermath of the December 2004 Indian Ocean tsunami in Asia, as well as various terrorist attacks, mounting health scares regarding avian flu, rising energy prices, and other political and economic uncertainties [2]. While particular regions and individual destinations suffered serious losses (at least in the short term), the global tourism industry itself remained surprisingly resilient and continued to rebound since the destruction of the World Trade Towers in New York in 2001. The World Tourism Organization [3] remains optimistic about the industry even in those countries shattered by the Indian Ocean tsunami, predicting that tourism will regain its pre-tsunami strength by the winter season of 2006-2007. One of the most important predictions recently made by the United Nations World Tourism Organization (UNWTO) Panel of Experts was that the tourism industry "can no longer expect a normal year," and that given mounting global environmental and social risks and uncertainties, each year will bring new challenges (and opportunities) [2]. While it is impossible to predict future social and political upheavals with much certainty, the UNWTO forecast is particularly relevant in terms of the growing scientific consensus that climate change is affecting extreme weather events, increasing the intensity, and perhaps the frequency, of hurricanes and flooding, particularly in coastal zones [4,5]. These increases are particularly important in low and middle income countries since fatalities per event, direct economic losses as share of income are inversely related to national per capita income, and insurance coverage is low or nonexistant [6]. Moreover, while the risks/costs of climate change and extreme weather events continue to rise in terms of human lives, decimated economies, and damaged ecologies (especially in poorer countries), it is increasingly clear that these escalating costs are due to deep social and ecological vulnerabilities as much as by "natural" hazards [7-9]. Recent shifts in thinking and dealing with disasters have moved away from conceptualizing "hazards" and "disasters" as one time events to viewing them as longitudinal processes with diverse causes and consequences; to recognizing that "disasters" reveal the complex interrelationships between ecological systems and human societies; to emphasizing preparation, planning, mitigation, and reconstruction, as well as emergency recovery; and to focusing on reducing social and ecological vulnerability and enhancing "resilience" of diverse groups and environments.

The recognition by the UNWTO Expert Panel of ongoing risks and uncertainties affecting tourism is particularly relevant for the countries of Central America, which have seen significant growth in international tourism over the last two decades. The increase is due to several factors including U.S. consumer beliefs that the region is "safer" than other regions of the world, significant increases in the number and quality of accommodations, and enhanced transportation opportunities, integrated through aggressive joint efforts by Central American countries to promote international tourism as a major avenue 
of economic development [10]. Between 1990 and 2005, the number of international tourist arrivals to Central America grew from approximately $2 \mathrm{M}$ to $6.6 \mathrm{M}$ annually $(230 \%)$. Since 2000 , average tourist arrivals to the region grew almost $9 \%$ annually, even in the aftermath of widespread declines in international travel following 11 September 2001. In the last two years, international tourist arrivals to the region grew $17.8 \%(04 / 03)$ and $13.6 \%$ $(05 / 04)$, significantly surpassing the global growth rates, which were $10 \%$ and $5.5 \%$ for the same periods. While international travellers to Central America make up less than $1 \%$ of the total number of international tourists, foreign exchange earnings from the tourism industry have become a major contributor to the economies of the region [2]. For example, in 2004, tourism receipts were more than $50 \%$ of the Gross National Products (GNP) of Costa Rica, Belize, Honduras, and Panama, and more than 20\% in Guatemala and El Salvador [11].

\section{Hurricane Mitch: the perfect storm}

The Central American isthmus is one of the most disaster prone regions of the world, an area that has experienced severe (and ongoing) social conflicts, widespread inequalities and poverty, as well as dangerous "natural" events (hurricanes, earthquakes, volcanic eruptions, floods, droughts, and landslides). Yet, as noted above, a growing number of scholars, policy makers, and disaster specialists have pointed out that it takes more than an extreme event to produce a "disaster." This was made incredibly clear when Hurricane Mitch hit Central America in 1998. Figure 1 traces the path of Hurricane Mitch from 22 October to 6 November 61998.

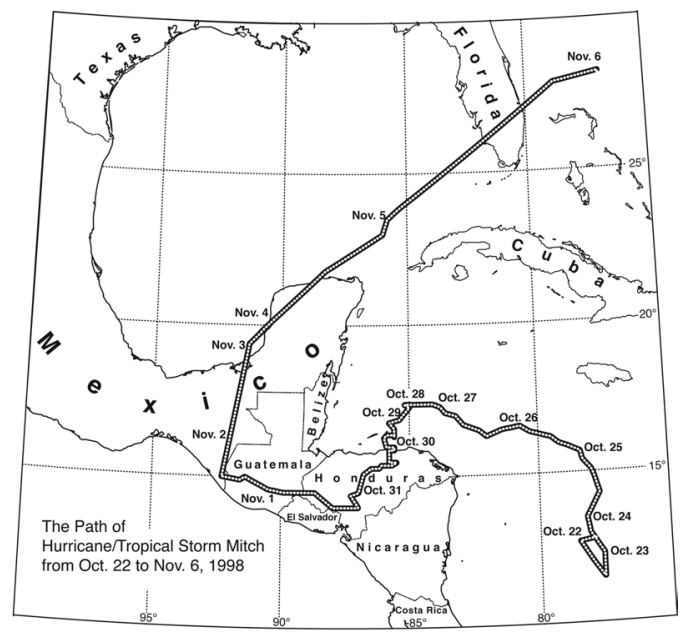

Figure 1: Path of Hurricane/Tropical Storm Mitch. 
Hurricane Mitch affected most Central American countries but had the most severe impacts in Honduras. Late in the hurricane season, it quickly developed into a catastrophic, Category 5 hurricane with wind speeds in excess of 200 miles per hour and took deadly aim at Honduras. Described as the most destructive Atlantic storm in the last 200 years, it stalled with its eye over Honduras' premier tourist destination, the Bay Islands where it stayed for 39 hours before it made landfall along the Honduran North Coast. While lingering off the coast for several days, Mitch absorbed enormous amounts of water from the ocean. Even after wind speeds diminished and it was downgraded to a tropical storm, it dropped as much as six feet of rain in some places as it moved south across Honduras and Nicaragua before turning west and passing over El Salvador and Guatemala. In Honduras, the intense rainfall caused major flooding in lowland areas and in river basins and brought about deadly landslides on deforested mountainsides significantly altering the topography in many areas. Estimates of the dead approached 10,000 for the entire Central American region with almost 6,000 Hondurans dead and 8,000 legally missing and presumed dead. An estimated 3 million people (about $50 \%$ of the population) were affected: 1.5 million people were displaced and homeless; more than 12,000 were injured; most of the social infrastructure such as schools, and health facilities were destroyed or badly damaged; $33 \%$ of the buildings in the capital city of Tegucigalpa were destroyed, and significant increases in many water borne diseases and malnutrition occurred. Destruction of roads, bridges, electrical plants and grids, water and sewage systems, and communication systems were far-reaching. An estimated 70\% of Honduras' physical infrastructure was seriously damaged including 169 major bridges, all major highways, and most secondary roads. Total monetary losses for the region were estimated at about US\$6 billion, while loss estimates for Honduras alone were in excess of US\$4 billion.

The burden of recovery was made even more difficult in light of the economic impacts of Hurricane Mitch. In addition to sweeping away people, homes, and entire villages, massive flooding also destroyed industrial and commercial sites while simultaneously depositing a wide variety of chemicals and other toxic materials in the soils and aquifers as well as in coastal and marine environments. Vast areas of agricultural land were flooded, destroying at least $80 \%$ of agricultural crops, both those grown for domestic consumption and for export. An estimated twenty percent of Honduras' most important export crop, coffee, was lost, but actual losses were much higher because damage to roads hampered carrying out the coffee harvest or prevented the transport of harvested coffee to markets. Bananas, which rank second in providing foreign exchange to Honduras, were harder hit with loss estimates of US\$800 million. Virtually all banana plantations along the North Coast were completely flooded, reducing production to about $5 \%$ of normal and creating as much as $80 \%$ unemployment in the industry. Honduras' third most important export crop, cultivated shrimp, also suffered devastating losses (approximately US\$150 million) due to both inundation and contamination that affected the majority of shrimp farms along the Gulf of Fonseca in southern Honduras. Small and medium sized hillside 
farms, largely cultivated by peasant farmers, fared no better than larger export oriented farms and plantations. Hillside farms were stripped of topsoil by heavy rainfall and landslides and many farms located in highland valleys were buried under deep layers of debris and sediment. In addition to the economically devastating loss of foreign exchange brought about by the destruction of export crops, enormous unemployment throughout the agricultural sector significantly impeded the ability of Honduran families to recover.

\subsection{Tourism as a key development strategy}

By 1998 , tourism receipts ranked $3^{\text {rd }}$ (behind bananas and coffee) in generating foreign exchange earnings in Honduras, the result of a decade of promotion by the government of Honduras $(\mathrm{GOH})$ and the private sector with donor support [12]. Although affected, the major tourist destinations of the Bay Islands and the Archaeological site of Copan were relatively unscathed after Mitch. With the widespread decline in agriculture, the GOH saw tourism (along with the maquila sector) as the pillars of economic recovery. Enhanced public - private collaborations (with international donor support) commenced quickly. The Honduran Institute of Tourism (IHT), a government agency, set up a Hurricane Mitch Response Team almost immediately and engaged a U.S. public relations firm, Egret Communications, to carry out the IHT strategy, create a marketing plan, and handle damage control including creating an Internet website. These efforts all were focused on bringing tourists back to Honduras, especially on promoting foreign tourism investment in the Bay Islands and the North Coast the areas targeted for intensive tourism development. In addition to economic incentives, the GOH Reconstruction Plan also established political economic measures as part of their strategy to promote tourism through enhanced foreign investment. These measures included accelerated passage of the reform of Article 107 of the Honduran Constitution by the Honduran Congress and stepped up processes of political decentralization (which delegated many reconstruction activities to municipalities) and the privatization of several state owned industries such as telecommunications, energy, and major port facilities. While all these measures were designed to further neoliberal economic expansion, the reform of Article 107 was particularly significant because the reform made it legal for foreigners and foreign corporations to purchase lands and own infrastructure on the Caribbean and Pacific Coasts and on all islands, which had previously been prohibited by the constitution. The GOH estimated that this reform would generate at lest US\$500 million in the form of hotel and resort construction. Widely supported by owners of tourism firms, one hotel owner stated "Article 107's reform will enable Honduras to become a player in the world tourism arena." As I have described in detail elsewhere, the reform was very controversial and contested (sometimes violently) by indigenous groups (especially the Garifuna and the Native Bay Islanders) and coastal communities who lost land, homes, and livelihoods in the process [12]. The often conflictive process of wresting control of coastal areas from local, coastal peoples (AfroCaribbean Bay Islanders, Garifuna, and poor ladinos) was often described to me as a "land grab" designed to further the ladinoization/hispanization of the islands 
and coastal zones by the "Spaniards" in Tegucigalpa [12]. This resistance continues today, as coastal peoples lose land and livelihoods in the name of tourism development and the promise of jobs. Another important component designed to promote tourism (but which also wrenched control of coastal zones from local people) was the designation of both terrestrial and marine protected areas. Done in the name of environmental protection and management, these designations often have been, in effect, flagrant examples of "coercive conservation" involving little if any participation by local peoples [14]. Since the immediate post-Mitch period, the $\mathrm{GOH}$ has continued to promote tourism as a major avenue of economic development, with support from major international donors including the World Bank, the International Monetary Fund (IMF), the Inter-American Development Bank (IDB) and the United States Agency for International Development (USAID).

\subsection{Honduras after Hurricane Mitch}

The United States has had great political and economic influence in Honduras since the early 1990s and beginning in the 1970s became a major staging area for U.S. troops during the Cold War. By the 1980s, U.S. corporations controlled more than $60 \%$ of the Honduran economy [14]. Despite this attention (or perhaps because of it), Honduras was characterized by widespread poverty and environmental destruction when Hurricane Mitch hit in 1998. At that time, the country was struggling with a draconian structural adjustment program and increasing public hostility; a stagnating economy; one of the lowest GDPs per capita in Latin America; increasing landlessness of peasant farmers; high levels of poverty ( $70 \%$ of the total population living below the absolute poverty level); worsening inequalities of all kinds; widespread malnutrition; and high rates of mortality and morbidity [15]. Moreover, Honduras ranked last of the Central American countries according to the UN Human Development Index in 1998.

The United States continues to be a powerful force in the country. The U.S. is Honduras' most important trade partner, accounting for 50\% of Honduran exports and $41 \%$ of Honduran imports. The ratification of the Central AmericanDominican Republic Free Trade Agreement (CAFTA) has been promoted by the U.S. on the grounds that it will increase foreign investment, exports, and employment in Honduras. However, with a GDP of about $\$ 6.6$ billion (an average of $\$ 962$ per capita), Honduras remains one of the poorest countries in Latin America. In 2001, the IMF and the World Bank approved Honduras' Poverty Reduction Strategy Paper (PRSP). With Hurricane Mitch reconstruction largely over and most macroeconomic targets met to their satisfaction, the IMF approved a three-year US\$107.6 million Poverty Reduction and Growth Facility (PRGF) agreement for Honduras to support the government's economic program. The expansion of international tourism was a central tenant in Honduras' original application and remains so in the subsequent annual progress reports the country is required to submit. The approval of this agreement allowed Honduras to receive around US\$324.3 million during 2004 and US\$186.6 million during 2005 in new disbursements from other international financial 
institutions and bilateral donors, and paved the way for multilateral debt relief of approximately US $\$ 1.1$ billion over the next fifteen years. The IMF contends that the debt relief will contribute to greater investment and economic growth [16]. It remains to be seen whether this will occur.

Immediately after Mitch, the president of Honduras declared Martial Law, suspended civil liberties, created an authoritarian (and many would say corrupt) Reconstruction Plan designed by his political cronies. These acts, along with the passage of the controversial constitutional reform, accelerated privatization of industries and services, and widespread hostility to structural adjustment in the form of the PRSP, stimulated increasing civil protests and the emergence of hundreds of new civil society groups in the country. The severe measures of the $\mathrm{GOH}$ also attracted the attention of multilateral and bilateral donors and international nongovernmental organizations (NGOs) on which the country depended for financial assistance. Several important things came about: increased cooperation among civil society groups and between civil society groups, labour unions, human rights groups, other issue oriented groups, and donors; increased participation by these coalitions in reconstruction plans and activities; and increased power of these coalitions to make political demands. The result has not been the comprehensive transformation of Honduran society as envisioned in the immediate aftermath of Hurricane Mitch including the reduction in social and ecological vulnerabilities as proposed in the Stockholm Declaration of 1999. However there has been an opening up of the political landscape with additional political space for civil society groups and the (still unrealized) potential of transforming the country from within. In the aftermath of Mitch, individuals and institutions seem to have perceived the future through one of two lenses (windows of opportunity). The first vision saw reconstruction as a means to recover economically without recreating existing social and ecological vulnerabilities, as a means to address root causes of vulnerability and enhance resilience; and as a means to enhance true democracy and promote equity. The second window perceived reconstruction as a means to promote capitalism through privatization and other neoliberal economic policies and practices, especially through the expansion of international tourism. In reality both visions materialized to some degree [15].

\subsection{Tourism: a "successful" development strategy for Honduras?}

According to a few criteria, tourism development has been a very successful development strategy for Honduras since Hurricane Mitch. Figure 2 shows significant increases in international tourism arrivals, tourism receipts, and number of cruise ship passengers to Honduras between 1995 and 2005 [17]. Since 1997 (before Mitch), the number of tourist arrivals has increased 150\% (from about 300,000 to 750,000), tourism receipts have risen $200 \%$ (from approximately US\$146 million to US\$431 million), and the number of cruise ship passengers has grown from less than 25,000 to about 226,000 passengers per year. 


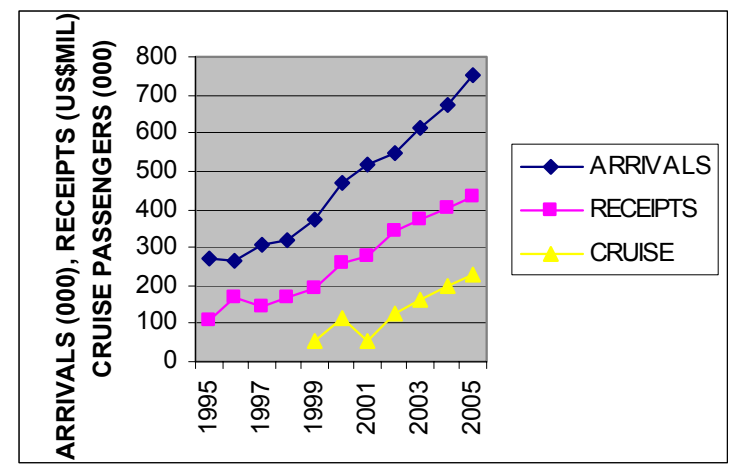

Figure 2: Tourist arrivals, receipts and cruise passengers to Honduras, 1995-2005.

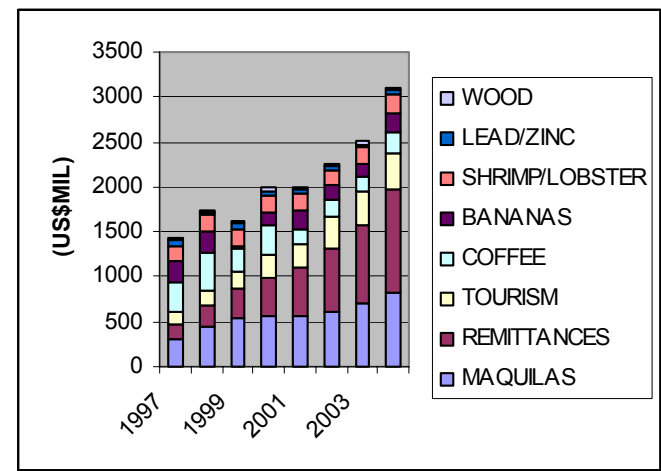

Figure 3: Relative contribution of key exports 1997-2004 (US\$M).

According to the Latin American Globalization Index (of 17 Latin American countries) computed by the Latin Business Chronicle, on the basis of 6 factors that measure each country's links with the outside world, Honduras is the $4^{\text {th }}$ most "globalized" country in Latin America - largely on the basis of the high percentage of tourist receipts, imports of goods and services, and remittances to GDP [11]. While an increase in tourism revenues may be a judged a "positive" trend, a growing dependence on imported goods and services, and on foreign remittances are much more problematic. In fact, while total export earnings have grown significantly, major shifts in the relative contribution of key exports have occurred since Hurricane Mitch. These are clearly shown in figure 3 [17].

Currently, foreign exchange earnings from remittances, the maquila sector, and tourism comprise the three principal sources of foreign exchange. Since 1997, the relative contribution from remittances has grown from 11 to $37 \%$ of total key exports, maquilas from 22 to $27 \%$, and tourism from 10 to $13 \%$. This suggests that the true growth in the Honduran economy is not from the tourism industry but rather from Hondurans who no longer are able to make a living in 
the country and have been compelled to migrate elsewhere and send money home. When viewed within the context of the larger economy, especially from the perspective of people trying to earn a living, the growth in tourism is truly problematic.

\section{Conclusions and recommendations}

Most assessments of post-disaster reconstruction in Honduras conclude that the efforts have largely addressed symptoms rather than root causes, and thus the probability is high that repeated disasters of similar severity will occur. While donor pledges were exceptionally high (>US $\$ 2.7$ billion) they were only about $50 \%$ of necessary recovery costs [18]. Further, while the tourism and maquila sectors have grown significantly, national economic performance remains below pre-disaster estimates. In a very real sense, disaster recovery and rehabilitation efforts have been disarticulated from economic development efforts, particularly in terms of improving the lives and livelihoods of most Hondurans. It is here especially that tourism development could have, and should have, played a major role, a meaningful link between disaster recovery/rehabilitation and sustaining or even improving lives and livelihoods, especially with the surge of civil society groups and increased donor attention. Thus, despite high levels of foreign assistance, PRSPs, and other measures, poverty levels have not been reduced significantly. It is remittances that are the true "growth sector" of the Honduran economy. Moreover, there are some indications that nutritional status has declined and that income and health inequality have gotten worse. Thus, postMitch recovery and reconstruction efforts largely failed to reduce the longitudinal, historical, social, and ecological vulnerabilities that were the root causes of the "disaster." Disaster capitalism, thus, has limited usefulness in explaining the complexity of the processes that encompass the ongoing disaster because it focuses on only one aspect, the expansion of capitalism and not on another and potentially significant aspects - the expansion of civil society and the growth in tourism. The current situation in Honduras is much more complicated than can be described and/or explained by disaster capitalism alone - processes that have been going on for a very long time and demand direct and serious attention.

\section{References}

[1] Klein, N., The rise of disaster capitalism. The Nation, May 22005. http://www.thenation.com/doc/20050502/klein

[2] World Tourism Organization (WTO). UNWTO World Tourism Barometer, 4(1), January, 2006. http://www.worldtourism.org/facts/menu.html

[3] World Tourism Organization (WTO). Post Tsunami Re-Assessment: Growing Demand, Limited Supply, November, 2005. http://www.worldtourism.org 
[4] Trenberth, K., Uncertainty in hurricanes and global warming. Science, 308, pp.1753-1754, 2005.

[5] Adger, W.N., Hughes, T.P., Folke, C., Carpenter, S.R., \& Rockstrom, J., Social-ecological resilience to coastal disasters. Science, 309, pp. 10361039, 2005.

[6] Linnerooth-Bayer, J., Mechler, R., \& Pflug, G., Refocusig disaster aid. Science, 309, pp. 1044-1046.

[7] Oliver-Smith, A., \& Hoffman, S.M., (eds). This Angry Earth: Disaster in Anthropological Perspective. Routledge: New York, 1999.

[8] Wisner, B., Blaikie, P., Cannon, T., \& Davis, I., At Risk: Natural Hazards, People's Vulnerability and Disasters. Routledge: London, 2004.

[9] Bankoff, G., Frerks, G., \& Hilhorst, D., (eds). Mapping Vulnerability: Disasters, Development, and People. Earthscan: London, 2004.

[10] Centro Latinoamericano para la Competitividad y el Desarrollo Sostenible (INCAE), Harvard Institute for International Development (HIID). Centroamerica en el siglo XXI. Alauela, Costa Rica, 1999.

[11] Latin American Business Chronicle. Latin American Globalization Index. Latin Business Chronicle, October, 2005. http://latinbusinesschronicle.com/reports/reports/lagi100305.htm

[12] Stonich, S.C., The Other Side of Paradise: Tourism, Conservation, and Development in the Bay Islands. Cognizant: New York, 2000.

[13] Stonich, S. C., The political ecology of marine protected areas. (Chapter 5). Tourism and Development in Tropical Islands, ed. S. Gossling, Edward Elgar Publishing: Bodmin, Cornwall, UK, pp. 121-147, 2003.

[14] Stonich, S. C., I am Destroying the Land: The Political Ecology of Poverty and Environmental Destruction in Honduras. Westview: Boulder, 1993.

[15] Stonich, S. C., An evaluation of Hurricane Mitch reconstruction: A political ecological perspective. Paper presented at the Annual Meeting of the Society for Applied Anthropology, Vancouver, British Columbia, March 28-April 1, 2006.

[16] United States Agency for International Development (USAID). Honduras Summary, 2006. http://www.usaid.gov.

[17] Honduras Institute of Tourism (IHT). Statistical database. Tegucigalpa, Honduras. http://www.letsgohonduras.com

[18] Telford, J., Arnold, M., Harth, A., \& ASONOG, Learning Lessons from Disaster Recovery: The Case of Honduras. Disaster Risk Management Working Paper Series no. 8, The World Bank: Washington, DC, 2004. 